\begin{tabular}{|c|c|c|}
\hline $\begin{array}{l}\text { FATIH } \\
\text { SULTAN } \\
\text { MEHMET } \\
\text { VAKIF UUNIVESIITESI } \\
2010\end{array}$ & $\begin{array}{l}\text { FSM İlmî Araştırmalar Insan ve Toplum Bilimleri Dergisi } \\
\text { FSM Scholarly Studies Journal of Humanities and Social Sciences } \\
\text { Sayı/Number } 15 \text { Yıl/Year } 2020 \text { Bahar/Spring } \\
\text { (C2020 Fatih Sultan Mehmet Vakıf Üniversitesi }\end{array}$ & 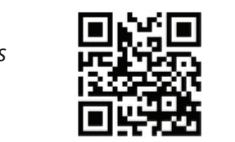 \\
\hline DOI: & http://dergipark.org.tr/fsmia & http://dergi.fsm.edu.tr \\
\hline Araştırma Makalesi / Research Article & Geliş Tarihi / Received: 04.03.2020 Kabul Tarihi / Accepted: 28.04.2020 & FSMIAD, 2020; (15): 231-260 \\
\hline
\end{tabular}

\title{
Modern Arap Şiirinde Sembolik Bir Figür Olarak İsâ Mesîh
}

İbrahim Usta*

\section{Öz}

Edebiyatın önemli akımlarından birisi de sembolizmdir. Bir edebiyat türü olarak şiirde sembolizm, şairinin "bir takım simgeler çerçevesinde meramını kapalı bir dille anlatımı" olarak tanımlanmaktadır. Klasik Arap edebiyatında çokça örneklerine rastladığımız bu akım, Arapların Avrupa edebiyatıyla tanışması sonucu tekrar belirgin hale gelmiştir. İlk olarak Charles Baudelarie ile Avrupa edebiyatında sahneye çıkmış olan sembolizmin Arap edebiyatına yansıması ise Temmuzî akımla zirveye ulaşmıştır. Arap toplumundaki gerek gergin siyasi ortam, gerekse şiirlerdeki kapalılık olgusundan kaynaklı anlam derinliğine ulaşma fikri, birçok şairin bu edebi akıma katılmasına sebebiyet vermiştir. Sembolizmin en önemli unsuru figürdür. Bu bağlamda modern dönem sembol figürlerden birisi de hiç şüphesiz İsa Mesih’tir. Mesih sembolü, nesirde Cebrâ İbrahîm Cebrâ ve Cibrân Halîl Cibrân, şiirde ise Bedr Şâkir es-Seyyâb, Halîl Hâvî, Mahmûd Dervîş, İzzeddîn el-Munâsara, Emel Dunkul ve Abdulvehhâb el-Beyâtî gibi modern şiir öncüleri tarafindan sıkça dile getirilir olmuştur. Hem Müslüman hem de Hristiyan şairler ifade etmek istedikleri anlamı Mesih çerçevesinde merhamet, umut, direniş, lider, 1zdırap, özdeşleştirme ve gurbet gibi bazı sembollerle anlatmaya çalışmışlardır.

Anahtar Kelimeler: Şiir, modern Arap şiiri, İsa Mesih, sembolizm.

Doç. Dr., Bingöl Üniversitesi Fen Edebiyat Fakültesi Doğu Dilleri ve Edebiyatı Bölümü Arap Dili ve Edebiyatı Anabilim Dal1, Bingöl/Türkiye, iusta@bingol.edu.tr, orcid.org/0000-00018631-6679 


\title{
Jesus Christ as a Symbolic Figure in Modern Arabic Poetry
}

\begin{abstract}
One of the important movements in literature is symbolism. As a literary movement, it is defined as an allusive expression of the mind and spirit of the poet within the framework of a number of symbols. This movement, which we find many examples in the classical Arabic literature, has reappeared as a result of the introduction of Arabs to the European literature. The reflection of symbolism, which first appeared in the European literature with Charles Baudelarie, reached its peak with the Tammuzi movement in the Arab literature. The idea of reaching the depth of meaning arising both from the tense political environment in the Arab society and the phenomenon of allusiveness in poetry has led many poets to participate in this literary movement. The most important element of symbolism is the figure. Undoubtedy, one of the symbolic figures of the modern period in this context is Jesus Christ. The symbol of Christ has been constantly mentioned by Jebra Ibrahim Jebra and Jibran Khalil Jibran in prose, and by the pioneers of the modern poetry such as Badr Shakir al-Sayyab, Khalil Hawi, Mahmoud Darvish, Izz ad-Din al-Musanara, Amal Dunqul and Abdul Wahhab al-Bayati in poetry. Both Muslim and Christian poets have tried to explain the meaning they want to express with some symbols such as mercy, hope, resistance, leader, affliction, identification and expatriate within the framework of Christ.
\end{abstract}

Keywords: Poetry, modern Arabic poetry, Jesus Christ, symbolism. 


\section{Giriş}

\section{Modernite Üzerine}

Modern dönem olarak isimlendirilen süreçle beraber insanoğlunun hem bireysel hem de toplumsal hayatında bazı değişiklikler göze çarpmaktadır. Sanayi devrimi, birinci ve ikinci dünya savaşları, kapitalist düzen karşısında insanın materyalist düşüncesi, kentleşme ve teknolojinin ilerlemesi gibi sebepler hayatın önemli kısımlarından biri olan edebiyata bakışımızı da değiştirmiştir. Bu etkilerin bir sonucu olarak ortaya çıkan modernizm kavramının özü aslında Batı'daki Rönesans, Reform ve Aydınlanma hareketleri sonrasında ortaya çıkmış, 1880'lerin sonlarından başlayarak İkinci Dünya Savaşı'nın çıkışına kadar sürmüş bir zaman dilimini kapsayan özel bir dönemdir. Batı'da "modernus" şeklinde ilk kez 13 ve 14. yüzyılda özellikle kiliseye bir tepki olmak üzere kullanılmaya başlayan bu ifade, terim olarak "geleneksel olanı yeni olana uydurma çabası içinde olmak" demektir.

Coğrafi ve bilimsel keşifler, reform ve Rönesans hareketleri, buhar gücünün keşfiyle beraber hızlı bir ivme kazanan sanayileşme ve kentleşme gibi faktörler modernizmin temellerini güçlendiren etkenlerin başında gelmektedir. Modernizm hareketinin sanat ve edebiyata yansıması ise 16 ve 17 . yüzy1ldaki Rönesans ve reform hareketlerinden başlayıp, 20. yüzyıldaki dünya savaşlarına kadar devam etmiştir. Bu yansımaların en önemlileri arasında sembolizm, ekspresyonizm, kübizm, fütürizm, konstrüktivizm, empresyonizm, dadaizm, sürrealizm, egzistansiyalizm gibi akımlar yer almaktadır. Modernizm, Descartes (1596-1650), Montesquie (1689-1755), Jean Jacques Rousseau (1712-1778) ve Emmanuel Kant (1724-1804) gibi bilim insanları vasıtasıyla sistematize edilerek, insan özgürlüğü, barış, evrensel ahlak, sorgulama, mutluluk ve insan aklına güven gibi ilkeler etrafında şekillenmiştir. Hayatın her alanına etkisi hissedilen modernizmin şüphesiz edebiyat ve sanata da bir kısım etkileri olmuştur. ${ }^{1}$ Bu etkileri şu şekilde sıralamak mümkündür:

Modernist yazarlar, gerek nesir ve gerekse şiirlerinde yeni bir anlam arayışına girerek, eski ve eskiye ait olan çok şeyi ya terk etmişler ya da reforme etmişlerdir. Eskiyi kısaca açmak gerekirse; aklımıza bir edebiyat türü olan klasisizm gelmektedir. Klasisizm, döneme egemen olan mutlak krallık rejimi ve toplumu etkisi altına almış feodal düşüncenin edebiyat sahnesine yansımasıdır aslında. Toplumsal yaşantıya ve devlet işlerine hâkim olan, insan hakları ve özgürlüklerini göz ardı

1 İ. Çetişli, Batı Edebiyatında Edebi Akımlar, Ankara, Akçağ Yayınları, 2017, s. 56; P. Safa, Edebi Akımlar ve Fikir Cereyanları, İstanbul, Boğaziçi Yayınları, 2007, s. 10-11. 
eden yasa ve kurallar, 1634 yılında kurulan Fransız Akademisi'nin dil ve edebiyat kurallarını belirlemesi, bu tip kuralcı ve şekil odaklı bir edebiyat akımı doğmasında etkili olan diğer faktörlerdir.

Klasik eserlerde, duygudan ziyade akla uygunluğu ve yatkınlığına dikkat edilmiş, akıl ve sağduyu öne çıkarılıp, akıl, duygular üzerinde denetleyici bir role sahip hale getirilmiştir. Eski Yunan ve Latin edebiyatının 1şık tuttuğu bu akıma konularını genellikle mitolojiden seçmektedir. Konu ve olayların gerçek olmasından ziyade gerçeğe yatkınlığı esastır. Konunun ne olduğu değil, nasıl işlendiği önemlidir. Kahramanlar kesinlikle sıradan insanlar olamaz; soylular, krallar ve kahramanlar ana karakter kadrosunu oluşturmaktadır. ${ }^{2}$

Modernist yazarlar eserlerinde yukarıda ana çerçevesini belirtmeye çalıştığımız klasisizm ve romantizmden kaynaklı gelenekselliğe karşı çıkmış, bilinç akışı, iç konuşma ve iç diyalog gibi modern tekniklerle dil ve anlatımda yeni ifade şekilleri aramıştır. Bu da doğal olarak romantizm, realizm, sembolizm ve sürrealizm gibi edebi akımların oluşumuna sebebiyet vermiştir. Modernist yazarlar, değişen yeni dünyanın temel sorunlarından olan daha çok bireysellik ve bireyin yalnızlığ 1 , bireysel ve toplumsal huzursuzluk, geleneklere isyan ve toplumsal hayattan kaçış gibi konuları geniş biçimde işlemişlerdir. Modernist yazarlar olay örgüsünü gözleme dayandırarak, birbirinde olan benzerlik ve farklılıkları ayırt etme, görme firsatı bulmuşlardır. Ayrıca bu tür olaylara realist yaklaşmışlar, başka bir tabirle gördükleri nesne veya olayları gerçeğe uygun ve göründüğü şekilde işlemişlerdir. Bu tür eserlerde, özellikle şiire yoğun kapalılık veya daha derin anlam katmak için alegori, mecaz, teşhis ve istiare türü anlatımlar önemsenmiştir. ${ }^{3}$

\section{Modernizm ve Arap Şiirinin Evrimi}

Arap edebiyatında çok önemli bir yere sahip olan şiir, yüzyıllardır Arap toplumundaki yeri ve önemini hiç kaybetmemiştir. Cahiliye döneminden itibaren toplumun gözü kulağı olan aruz ve kafiyeden müteşekkil klasik Arap şiiri, gerek Batı ve diğer milletlerle olan temas gerekse edebiyat alanındaki yeni oluşumların etkisiyle yerini serbest, mensûr ${ }^{4}$ ve mürsel $^{5}$ şiir gibi başka şiir türlerine

2 E. Kefeli, Batı Edebiyatında Akımlar, 2. bs., İstanbul, Dergâh Yayınları, 2014, s. 25; Çetişli, s. 63; Ş. M. 'İyâd, el-Mezâhibu'l-edebiyye ve'n-nakdiyye 'inde'l-'Arab ve'l-Ğarbiyyîn, Kuveyt, Âlemu'l-ma'rife, 1993, s. 28.

3 M. Küçük, Modernite Versus Postmodernite, İstanbul, Say Yayınları, 2011, s. 207-208.

4 Şiirin cümle yapısı ve ahengini koruyan ancak ölçü ve kafiyeye bağlanamayan; şiirsel bir konuyu, his, hayal ve düşünceyi kısa şekilde ve yoğun bir üslupla anlatan düzyazı türüdür.

5 Şiirin bir parçasında değişik vezin ve kafiyelerin yer aldığ 1 , iç armoninin önemsendiği şiir türüdür. 
bırakmak zorunda kalmıştır. İşlediği konular çağın ihtiyaçlarına uygun olarak sömürgecilik, reform, vatan sevgisi ve özlemi, yoksulluk, cehalet, hastal1klar gibi yeni ve modern temalar ele alınmıştır. ${ }^{6}$

“Modern Arap şiiri” tabirinin kökü her ne kadar Arapların 19. yüzyılda Avrupa edebiyatıyla tanışması sonucu ortaya çıtığı şeklinde ifade edilse de aslında bu durum; Emevi döneminden başlayıp, bir dizi evrim sonucunda son şeklini almış süreç olarak ifade etmek mümkündür. Başka bir ifadeyle klasik Arap şiirinin bir takım evrelerden geçerek, serbest şiir formuna geliş sürecini şu şekilde özetlemek mümkündür: Klasik şiirde göze çarpan en önemli husus, şüphesiz çöl hayatının kaba tasviridir. Şöyle ki; Cahiliye dönemi kasidelerinde; şair, sevgilisinin ayrılıp gittikten sonra geride bıraktığı kalıntılar karşısında durup ağlamakta ve sevgilisiyle birlikte geçirdiği güzel günleri hatırlayarak üzülmekteydi. Bu durumu da "nesîb" adı verilen kısa bir pasaj ile tasvir etmekteydi. Şiirin ikinci kısmı olan ve "atlâl" adı verilen pasajda ise; metruk mekânlarda durup anıları yâd etme ile devam edip son olarak şairin atını veya devesini överek çöl hayvanları ile ilgili teşbih ve tasvirler yaparak çöl maceralarını, yaşamış olduğu bedevi hayatını ve mücadelesini anlatarak bitirmekteydi. ${ }^{7}$ Klasik Arap kasidesinin bu tarzı ilk olarak Emeviler dönemi şiirinde biraz daha değişikliğe giderek ifadeleri daha edebî, tasvirlerin daha yumuşak olmasına önem verilmiştir.

Klasik kasidedeki bu değişim Abbâsî döneminde de devam etmiştir. Şöyle ki; Abbâsî dönemi şairleri, klasik şiirdeki üzüntüyü tasvir etmek yerine, mutluluğu ve devam etmesi gereken yaşama sevincini ifade ederek; sarayları, cariyeleri, bağ, bahçe, taştan örülmüş evlerini, evlerinin kapılarını, duvarlarını, perdelerini, oturdukları sandalyeleri, kullandıkları ev eşyalarını, müzik aletlerini kısacası medeni hayatın yeni objelerini tasvir etmekteydiler. ${ }^{8}$ Abbâsî dönemi şiirinde göze çarpan bir diğer olgu da, bu dönem şiirinde Cahiliye dönemi övgü, yergi, aşk, savaş gibi klasik şiir konuların yanı sıra doğal felaketler, buna bağlı ortaya çıkan hastalık, yaşlılık, gençlik, kıskançlık, avcılık gibi gerçek yaşamla ve toplumsal durumlarla ilgili soyut konular da bu dönem şiirinin içinde yer almaya başlamıştır. Bilindiği üzere Cahiliye Arapları şiirlerinde descriptive dream şeklinde isimlendirilen ve daha çok somut kavramlar olan şekle benzeterek tasvir etmeyi kullanmışlardır. Türkçe'de betimsel hayal veya tasavvur olarak tercüme edebileceğimiz bu olgu, Abbâsî döneminde daha çok imaginative dream, yani; ibdâî/ yaratıcı hayal veya kurgu şeklinde karşımıza çıkmaktadır.

6 L. Şeyho, Târihu'l-âdâbi'l-'Arabiyye, Beyrut, Dâru'l-meşrik, 1991, s. 25.

7 N. Çetin, Eski Arap Şiiri, İstanbul, Kapı Yayınları, 2011, s. 59.

8 K. Demirayak, Abbasi Dönemi Arap Edebiyat,, 1998, s. 17. 
Yine şiirin evrimleşmesiyle ilgi başka aşama ise Fars, Hint ve Yunan kültürlerinden pek çok eserin tercüme edildiği ve Arapların yabancı milletlerle ilk olarak kaynaştığ 1 bu devir, Arap nesir ve şiirinin gelişme yaşadığ 1 dönem olmuştur. Hayalî bir kahramanın başından geçen olayların hayalî bir hikâyeci tarafından dile getirildiği kısa hikâyeler olarak adlandırılan makâmeler, Arap ufkunu daha da açarak, tercümelerin de vasıtasıyla felsefe ve mantık gibi bazı unsurlarla harmanlanarak didaktik şiirlerin ortaya çıkmasına vesile olmuştur. ${ }^{9}$

Abbâsî dönemi şiirindeki değişiklilerinden bir tanesi de nağme kaygısından dolayı şiirlerin vezinlerinin daha sadeleşmiş, şiirdeki müzikalite bazen anlamdan daha önemli hâle gelmeye başlamasıdır. Bu sebeple klasik Arap vezinlerinin dışında "mudârie", "muktadab", "mutedârik" ya da "mutekârib" gibi yeni vezinler oluşturulmaya çalışılmıştır" ${ }^{10}$. Ayrıca recez, urcûze, zecel, mevâliyâ, kâne ve kâne, kûma ve muvaşşahalarla başlayan Arap şiirindeki yenilik arayışları yine bu dönem ortaya çıkmış ve tüm bunlar modern dönemde Batı edebiyatının derin ve nüfuzlu etkisinin, Arap coğrafyasındaki tarihler boyu ezilmişliğin verdiği bir başkaldırı ile birleşerek, daha fanatik bir hale gelmiş ve bu şekilde serbest şiire evrilmesine sebep teşkil etmiştir. ${ }^{11}$ 20. yüzylldan itibaren Modern Arap şiirinde serbest şiir denilen bir olgu ortaya çıkmıştır. Buna göre şairlerden bir kısmı vezin ve kafiyeden vazgeçmezken, diğer bir grup ise şiirdeki vezin ve kafiye anlay1şında bir takım değişiklikler yapmışlardır. Onlara göre bu tür şiirlerde aslolan fonetik ritim ve melodi olup, şairin düşünce ve hayal dünyasındaki gizem bu şekilde ortaya çıkmaktadır. Bu grup şairlere göre klasik kalıplar, duygu düşünce ve hayallerin taşımacısı olmakta yetersiz kalmaktaydı. İşte bu yetersizliği gidermek için bu akımın öncüleri serbest şiir düşüncesini öne sürmüşlerdir. Serbest şiir iki tür olarak ortaya çıkmıştır. Mensur şiir ve nesir kasidesi diye anılan tür, şiirin cümle yapısı ve ahengini koruyan ancak ölçü ve kafiyeye bağlanamayan; şiirsel

9 İ. Usta, İslam Öncesi Arap Mitolojisi, Ankara, Ankara Okulu Yayınları, 2019, s. 52.

10 Mudârie: Bu bahir Arap ve Fars şiirinde ortak kullanılan bir vezin türü olup, daha çok "mefầ $̂$ lun fầ İlâtun" şeklinde kullanılmaktadır. Araplarda ise daha çok çok "mefâê̂l fầ İlâtun" kalibında kullanılmaktadır.

Muktadab: Tek bir kalıbı olan bu vezin teorik olarak her ne kadar "mef" ûlâtun mustef"ilun mustef ilun" olan bu bahir, günlük kullanımda dasece "mef ûlâtun mustef" ilun" şeklindedir Mutedârik: Altı kalıbı olup esas îtibâriyle dört "fầilun" veya dört "fe ilun"dan meydana gelen aruz bahri.

Mutekârib: On kalıbı olup, dört "fe ûlun" ve "fe'ûlun fe êlun fe'ûlun fe' ûl" şeklinde kullanılan aruz bahri. .(Geniş bilgi için bkz: M. Fâhûrî, Mûsîkâ eş-Şi 'ri'l- 'Arabî, Haleb, Menşûrât kulliyyeti'l-âdâb bi Câmi'ati Haleb, 1996, s. 25, 99, 108 ve 113.)

11 M. M. Heddâre,.Dirâsâtun fi'l-edebi'l- 'Arabiyyi'l-hadîs, Beyrut, Dâru'l- 'ulûmi'l- Arabiyye, 1990, s. 64 . 
bir konuyu, his, hayal ve düşünceyi kısa şekilde ve yoğun bir üslupla anlatan düzyazı türüdür.

Mensur şiirde olay örgüsü de vardır. Bu özelliğiyle, öykü ile şiir arasında bir tür sayılmaktadır. Modern Arap şiirinde, nesir şiir ilk olarak 1869'da Rızkullah Hassûn (1825-1880) tarafindan denenmiş, 1905 yılında Cemîl Sidkı ez-Zehâvî (1863-1936) ve Emîn er-Reyhânî (1876-1940) tarafından tekrar ortaya çıkarılmış, 1908 yılında Halîl Mutrân (1872- 1949) tarafından yayımlanan Dîvânu Halîl adlı eserinde devam ettirilmiştir. Ahmed Zekî Ebû Şâdî (1892-1955) ile ölçüye dayalı bir serbest vezinle devam ettirilen serbest şiir, 1940'ların sonlarında ortaya çıkan Mehcer ve Apollo ekolü şairleri ile zirveye ulaşmıştır. 1947 yılında, Bağdat Yüksek Öğretmen Okulu'ndan mezun iki genç Iraklı şair Nâzik el-Melâike'nin (1923-2007) el-Kûlîrâ (Kolera) ve Bedr Şâkir es-Seyyâb'ın (1926-1964) Hel kâne hubben ${ }^{12}$ ? (Aşk mıydr?) isimli şiirleri nesir şiirinin zirve noktası sayılmaktadır. ${ }^{13}$ İkinci tür olan mürsel şiir ise; şiirin bir parçasında değişik vezin ve kafiyelerin yer aldığı, iç armoninin önemsendiği şiir türüdür. En önemli temsilcileri Nizâr Kabbânî (1923-1998 ve Kîlânî Sened(1925-1979)'dir. ${ }^{14}$

\section{Sembolizm ve Modern Arap Şiiri Üzerine Yansımaları}

19. Yüzyılın son çeyreğinde Fransa'da parnasizme ${ }^{15}$ tepki olarak doğmuş bir ekol olan sembolizm; genelde sanat, özelde ise edebiyatı kapsayan bir sanat akımı olan sembolizm; gelenekten bütün bir kopuşu sağlamak amacıyla ortaya çıkmıştır. Sanat dalları ile edebiyatta yenilikçi deyişler, olağandışı sunum teknikleri ve yepyeni söylem biçemleriyle yaratma etkinliği sağlamıştır. Bu düşünceye göre dünya ve dünyadakiler yani gördüklerimiz bir yanılsama, hayalden ibarettir. Sembolistler, parnasizm ve realizmin insanları karamsar ve mutsuz bir hale getirdiğini öne sürüp şiirin sınırlarını kaldırmayı, müziği andıran şiirler yazmayı savunmuşlardır. Bu sayede duyguların en derinine erişebilmeyi amaçlamışlardır. Eserlerinde mecaz ve sembollerle örülü, örtük bir anlatım ve değişken anlamlı ifadeler işle-

12 Bu şiir şairin serbest ölçü ile yazdığı ilk(1948) şiirdir. Şair, "Unşûdetu'l-Matar” (Yağmurun Şarkıs1) isimli eseriyle de (1951) çok meşhurdur.

13 Z. Ceylan, Modern Arap Şiirinde Mito-Poetik İsyan, Konya, Çizgi Kitabevi, 2019, s. 29-30.

14 S. H. el-Ceyyûsî, el-Ittticâhât ve'l-harekât fi'ş-şi'ri'l-'Arabiyyi'l-hadîs, terc. Abdulvâhid Lu'lu'e, 2. bs., Beyrut, Merkezu dirâsâti'l-vahdeti'l-'Arabiyye, 2007, s. 597; M. Yalar, Modern Arap Şiiri, Bursa, Arasta Yayınları, 2003, s. 41.

15 19. yüzy1lın 3. çeyreğinde Fransa'da romantizme tepki olarak doğan parnasizm aslında roman ve hikâyede yoğunlaşan realizmin şiire bürünmüş halidir. Şiirden duyguyu çıkarmayı öngören parnasyenler duygusuz ve gerçekçi şiiri yazmanın yollarını aramışlardır. Romantizmin içe dönük, duygusal anlatımına karşın parnasizm dış dünyaya yönelmeyi ve onu yansıtmayı seçmiştir. 
mişler ve bunu şiirin zenginliği olarak görmüşlerdir. Genel olarak günbatımları, seher vakitleri, ay 1şığı, tenhalıklar gibi anlardan faydalanarak şiirin iç musikisini sağlayarak okuyucuya anlatılanı sezdirmeye çalışmışlardır. Onlar için şiir bir besteden farksızdır. Kafiye ve ölçüyü ikinci plana atmışlar ve yeni nazım biçimleri üzerinde çalışmışlardır. Sembolistler kendilerinden önceki tüm şiir akımlarını yok saymış, sanat için sanat görüşünü benimseyerek toplumsal ve siyasi olayları kendi perspektiflerinden yeni enstrümanlarla yorumlamaya çalışmışlardır. ${ }^{16}$

Sembolizmin Arap edebiyatındaki yansımasına gelince; Avrupa'da ortaya çıkmadan çok önceleri de Arap şiirinde sembolizm çokça kullanılmaktaydı. Cahiliye şiirindeki kartal, köpek, eşek, aslan ve deve gibi figürler aslında birer semboldürler. Buna göre kartal uzun ömrü; köpek emanet ve vefayı; eşek sabır ve korkuyu; aslan kuvvet ve cesareti; deve ise bedevi hayatın tamamını sembolize etmektedir. ${ }^{17}$

Modern Arap edebiyatındaki önemli sembolist temsilcileri arasında Bişr Fâris(1907-1963), Yusuf el-Hâl(1917-1987), Salâh Libekkî(1906-1955), Edîb Mazhar(1898-1928), Yusuf Ğassûb(1893-1972), Sa îd 'Akl(1911-2014) ve Halîl Hâvî(1919-1982) gibi edebiyatçıları saymak mümkün olmakla birlikte; sembolist edebiyatın Arap edebiyatındaki zirvesi hiç şüphesiz Temmûzî hareketi ile olmuştur. ${ }^{18}$ Günümüz Arap dünyasında mevcut siyasal ve sosyal düzene karş1 başkaldırının bir ürünü olarak çağdaş Arap şiirinde ortaya çıkmış olan Temmuz hareketi adını Sümer mitolojisinde geçen, baharı ve yeniden dirilişi simgeleyen İnanna efsanesinden almaktadır. Temmûzî hareketi özellikle 1950’lerde Arapların İsrail ile olan savaşları ardından kaybettikleri topraklar nedeniyle entelektüel çevrelerde büyük tepkilere neden olmuştur. Arap toplumunu dünyadaki gelişmelerden habersiz, tarih girdaplarında uyumaya devam ediyor gören çağdaş Arap şairleri, kendilerine Arap toplumunu bu uykudan uyandırma misyonu yüklemekte, bu misyonu da daha ziyade doğanın canlanıp hayat bulmasını sembolize eden eski doğu medeniyetlerine ait verimlilik mitlerine vurgu yaparak yerine getirmeye çalışmaktadırlar. Bu akım sosyo-politik konulara dikkat çekmek, eleştirilerine derin bir boyut kazandırmak, kitleleri harekete geçirmek isteyen şairlerin sembolik ifadelerle tarzlarını yansıtan edebi bir akımdır. Bu akımın öncüleri arasında Cebrâ İbrahim Cebrâ (1920-1994), Yusuf el-Hâl, Bedr Şâkir es-Seyyâb, Halîl

16 Kefeli, Batı Edebiyatında Akımlar, s. 128; Çetişli, Batı Edebiyatında Edebi Akımlar, s. 121.

17 M. H. H. et-Tunusî, el-Hayâlu fi 'ş-şi 'ri'l-'Arabî, Dimaşk, el-Mektebetu'l-'Arabiyye, ts., s. 13-14; E. K. eş-Şâbbî, el-Hayâlu'ş-şi 'rî inde'l-'Arab, Kahire, Kelimât 'Arabiyye li’t-terceme ve'n-neşr, 2013, s. 12.

18 Heddâre, Dirâsâtun fi'l-edebi'l- 'Arabiyyi'l-hadîs, s. 60-62; el-Ceyyûsî, el-İtticâhât ve'l-harekât fi'ş-şi'ri'l-'Arabiyyi'l-hadîs, s. 514-517. 
Hâvî’yi zikretmek mümkündür. Ayrıca Adonis (1930-), 'Abdulvehhâb el-Beyâtî (1926-1999), Nâzik el-Melâike, Emel Dunkul ve Nizâr Kabbânî de bu akımdan etkilenen şahsiyetler arasındadır. ${ }^{19}$

\section{Bir Sembol Figür Olarak İsa Mesîh}

Modern dönem Arap şairleri şiirlerinde bir yandan Temmuz, İnanna, Osiris, Şehrazad, Adonis ve Sisifos gibi mitolojik şahsiyetleri, diğer yandan da Hz. İsa, Hz.Yusuf, Lazarus, Hallâc ve Seyf b. Ziyezen gibi tarihi şahsiyetleri sembolik bir olgu olarak kullanmışlardır. Biz bu çalışmada Mesih'in neden sembolik bir figür olarak kullanılmış olabileceği hususunda modern dönem eleştirmenlerin görüş ve fikirleri çerçevesinde bazı çıkarımlarda bulunmaya çalıştık. Araştırmalar, Mesih'in sembolik bir öge olarak kullanılmasının iki ana temele dayandığını göstermektedir. Bu durumun birinci ana sebebi, çağdaş dönem Arap toplumunun düştüğü siyasi buhrandır. Şöyle ki; genelde Müslümanlar, özelde ise Araplar için hayatta önemli bir yer tutan Filistin'in İsrail tarafından işgal edilerek, halkının mülteci konumuna itilmesi ve Arap liderlerinin bu konuda yeterli tepkiyi vermemesi, Filistin meselesini kanayan bir yara haline getirmiştir. Yaşanan bu trajik durum şairleri de olumsuz etkilemiş, bunun neticesinde Filistin meselesi -bir bakıma- şairlerin ortak figürü olmuştur.

Mesîh'in sembolik bir figür olmasının ikinci sebebi ise yine 1967 Arap-İsrail savaşındaki Arapların mağlubiyetidir. Bu mağlubiyetle Arap liderlerinin liderlikleri sorgulanır hatta eleştirilir bir hal almıştır. Bu durum karşısında şairler yeni bir (sembolik) lider arayışına gitmiş, sonunda Mesîh'i bulmuşlardır. Karşımıza şöyle bir soru çıkmaktadır. Hristiyanlık ve İslam'daki İsa Mesîh inancı taban tabana zıt olmasına karşın, Müslüman şairler şiirlerinde İsa Mesîh’i neden bir Hristiyan inancına göre sembolize etmişlerdir? Konuyu biraz daha açmak gerekirse; Hz. İsa, İslam inancına göre asla çarmıha gerilmemiştir. Allah O'nu yanına almış, buna karşın O'na benzeyen birisi çarmıha gerilmiştir. İslam'ın bu kesin görüşüne rağmen, Müslüman şairlerin birçoğu şiirlerinde Hz. İsa'yı çarmıhtaki Mesîh olarak telakki etmektedirler. Bu ikilemin ana kaynağı bizce inanç sorunudur. Şairlerin inanç ve fikirleri -her ne kadar- bu çalışmanın amacı dışında kalsa da, şunu söylemekte fayda görmekteyiz. Şiirlerinde Mesîh veya diğer mitolojik figürleri özgürce işleyen şairlerin çoğu seküler düşünceye sahip, dini değerlere uzak kalmış kişiliklerdir. Bu durum, inanca aykırı bir konuyu kendilerine özgürce işleme cesareti vermektedir.

19 N. Neşâvî, Medhal ilâ dirâseti'l-medârisi'l-edebiyye fì şi'ri'l-'Arabiyyi'l-mu'âsır, Cezair, Dîvânu'l-matbû'âti'l-câmi 'iyye, 1984, s. 271; Ceylan, Modern Arap Şiirinde Mito-Poetik Isyan, s. 237-239. 
Bunun birlikte Hz. İsa'nın modern Arap şiirinde sembolik bir figür olarak kullanılmasının muhtemel diğer nedenleri de aşağıda kısaca belirtilmiştir. ${ }^{20}$ :

İlk olarak; 1970 ve 1980'li yıllarda Araplarda ortaya çıkan nesir şiir adı verilen bu yeni şiir türünü tıpkı Hz. İsa'nın doğumu gibi edebiyat meydanında yeniden doğuş olarak kabul ederek, İsa'yı bu akımın sembolü haline getirmişlerdir.

İkinci olarak; Mesih'in hayatının son anlarında çektiğine inanılan azap, şairin günümüz kapitalist ve sanayi toplumunda çektiği acı ve 1stıraba benzetilmiş ve adeta idol olarak Mesih görülmüştür.

Üçüncü sebebe gelince; yine bu kapitalist sistemde hissettikleri yalnızlık ve başıboşluk hissini, Mesih'in kavmi tarafindan yalnız bırakılmasıyla özdeşleştirmişler ve neticesinde böyle bir sembol ortaya çıkmıştır.

Dördüncü olarak; modern dönem Arap şairlerinin çoğunlukla rejim karşıtlıkları veya muhalefetleri sebebiyle yaşadıkları işkence, hapis veya sürgün, onları Mesih'i sembolize etmeye itmiştir.

Beşinci sebep, başta mehcer şairleri olmak üzere, vatanları dışında yaşamak zorunda bırakılan şairler çektikleri gurbet ve vatan özlemlerini Mesihi sembolize ederek gidermektedirler.

Altıncı sebep, Mesih'in hem İslam hem de Hristiyan toplumunda kıyametin alametlerinden birisi olan kurtarıcı Mesih figürü olarak kabul edilmesi, şairleri Mesih'i sembolize etmeye sevk eden başka bir etken olarak telakki edilmektedir.

Son olarak modern dönemde dil ve edebiyat çalışmaları yapan ve modern Arap edebiyatında ürün veren birçok yazar ve şairin Hristiyan olması da Mesih' in sembolik bir figür olarak kullanılmasına sebebiyet vermiş olabilir.

$\mathrm{Bu}$ girişten sonra şairlerin Mesih tasavvurunun şiirlerine yansıması bazı başl1klar altında değerlendirmek yerinde olacaktır.

\subsection{Direniş ve Feda sembolü olarak Mesîh}

Sembolizmi "sanat için sanat" görüşünü benimseyerek toplumsal ve siyasi olayları kendi pencerelerinden birtakım işaretlerle yorumlayan çağdaş bir edebî hareket olarak tanımlamıştık. Aşağıda vereceğimiz örneklerde ise bunun tersi bir durum söz konusudur. Bunun sebebini şu şekilde açıklamak mümkündür: Sembolizm, ortaya çıktığı Avrupa'da toplumsal ve siyasi olaylara girmeden, sadece "sanat için sanat" anlayışı çevresinde şekillenmiştir. Bu akımdan etkilenen başta

20 A. Kabeş, Târîhu'ş-şi'ri'l-'Arabiyyi'l-hadîs, Beyrut, Dâru'l-cîl, 1971, s. 72; İ. 'Abbâs, İtticâhâtu şi'ri'l-'Arabiyyi'l-mu'âsır, Kuveyt, Âlemu>l-ma'rife, 1998, s. 164. 
Arap ve diğer toplumlar bunu kendi toplumlarının ihtiyacına göre şekillendirmişlerdir. İkinci Dünya Savaşı sebebiyle yaşanılan sefalet, 1945 yılında İsrail'in kurulması sonucu Filistin'in işgal altına girmesi, 1967 Arap-İsrail savaşı sonucunda Arapların yenilmesi ve Arap ülkelerinde darbeler sebebiyle yaşanan diktatörlükler, şairleri sembolizmi asıl amacından çıkararak adeta bir silah haline getirmelerine olanak sağlamışlardır. Mısırlı şair Abdulmu tî Hicâzî, "Bağdâdu ve'l-mevt/Bağdat ve Ölüm” isimli şiirinde zulüm altında inleyen Bağdat şehrini İsa'nın çarmıhta çektiğine inanılan acılara benzetmesi bu bakımdan güzel bir örnektir. Şaire göre hayat ve ölüm sadece nefes alıp vermekten ibaret olmayı, İsa ve bitkiler gibi öldükten sonra dahi dirilip mücadeleye devam edebileceğini anlatmaktadır. Bu bağlamda şair şöyle demektedir ${ }^{21}$ :

Ölmek toprağın altında gizlenmek değildir

Ve onun üzerinde yürümek değildir yaşamak

Ekin, toprakta başlar hayata

Ve onu yardığında başlar ölüm

Öyleyse sevgini yaşayana ver

Ve toprağa ver onu çiğnemeyi mübah sayanları

Sen çarmıhta bir defa da ölmeyeceksin ey Mesih

Çünkü Bağdat'ın çocukları savunmadalar

$$
\begin{aligned}
& \text { الموت ليس أن توارى في الثرى } \\
& \text { ولا الحياة أن تسير فوقه } \\
& \text { الزرع يبدأ الحياة في الثرى }
\end{aligned}
$$

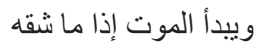

$$
\begin{aligned}
& \text { فامنح هو الك للذي يحيا، }
\end{aligned}
$$

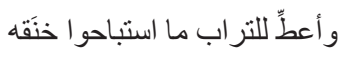

$$
\begin{aligned}
& \text { فلن تموت يا مسيح إنما } \\
& \text { على الصليب ينتهي من دقة } \\
& \text { بغداد طفلها على باب الدفاع }
\end{aligned}
$$

\subsection{Filistin'in Kurtuluş Sembolü Olarak Mesîh}

Filistinli şair Semîh el-Kâsım (1939-2014), aşağıdaki şiirinde Mesih'in çarmıha gerilmesi sebebiyle çektiği işkence ve 1stırabı, İsrail'in Filistinlilere yapmış olduğu baskı, yıldırma ve zulümle eş tutmaktadır. Hristiyan inancında çarmıh hem ölüm, hem de diriliş demektir. Bu sebeple Mesih'in çarmıha gerilmesinin, onun yeniden doğumu için bir aşama olduğu gibi Filistin halkının da dirilişi olacağını ifade etmektedir. Ayrıca çarmıh, Filistin için kurtuluş umududur. Şair "el-Kuds/Kudüs" isimli şiirinin bir kısmında şöyle demektedir ${ }^{22}$ :

21 A. Hicâzî, el-A 'mâlu'ş-şi 'riyyetu'l-kâmile, Kahire, el-Hey'etü'l-'amme li kitâb, 2014, s. 92.

22 S. el-Kâsım, el-A 'mâlu'ş-şi 'riyyetu'l-kâmile, Beyrut, Dâru'l- 'avde, 2003, III/318. 
Çarmıhımı hazırlayın

Aşk balkonu üzerindeki ölümün son anı

Sevgilimin yüzüne doğmaktadır

Ve parlamakta sevgilimin yüzü

Güneşin doğduğu Kudüs kubbesi üzerinde

Ölümüm ve dirilişim

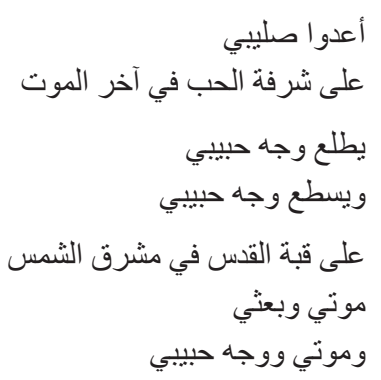

Sevgilimin yüzüyle ölümüm..

Filistinli şair Mahmûd Dervîş (1941-2008), “Şehîdu’l-uğniye/Şarkılar Şehidi” isimli şiirinde Mesih için kurulan çarmıhı, Filistinlilere uygulanan zulüm ve tecridin bir sembolü olarak kullanmıştır. Mesih burada Filistin sembolüdür. Şair, şöyle demektedir ${ }^{23}$ :

Duvar üzerine kurdular çarmıhı

Elimdeki zincirleri çözdüler

Kırbaç bir yelpaze, nal sesleri

"Efendim!" diye şaklayan bir nağme

Ölülere sesleniyor: Dikkat!

Hey... Sen!

Vahşi bir köpek şöyle havladi:

Senin yoluna birakırım

Eğer tahtımın önünde iki defa

Secde eder ve saygıyla öpersen elimi iki defa.

Veya tırmanırsan tahta çarmıha

Şarkılar ve güneş şehidi.

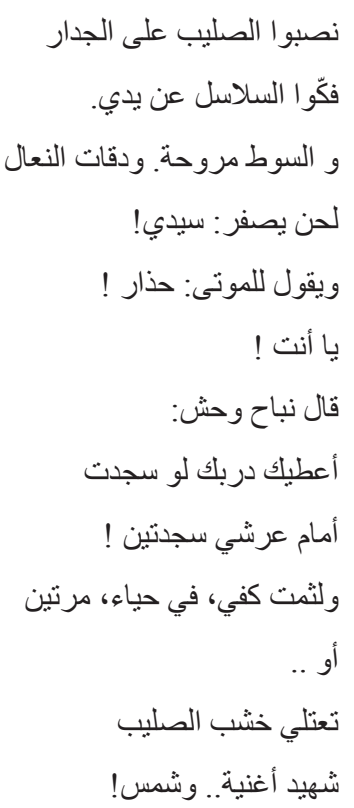

Muhammed Mehdî el-Cevâhirî (1899-1997) 'Uğniyetun ilâ Yâfa/Yafa'ya Şarkılar” isimli şiirinde İsrail zulmü altında inleyen Yafa kentini, Mesih'in zulme uğrayarak çarmıha gerilmesine benzetmiştir. Mesih burada Yafa kentinin sembolüdür. Şair şöyle demektedir ${ }^{24}$ :

23 M. Dervîş, Dîvân, Beyrut, Dâru'l-`avde, 2004, s. 102.

24 M. M. el-Cevâhirî, Dîvân, Beyrut, Beysân li’n-neşr ve’t-tevzî, 2005, I/193. 
Ey Yafa... Mesih'in zincire bağlanmış

Ayıp, demirden çarmıh üzerinde parçalıyor onu gırtlaklar

Kubbelerinin üzerinde bulutlar ağlıyor

Ve yarasalar uçuyor

Ey kırmızı gül, ey bahar yağmuru..

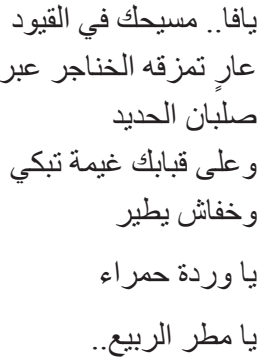

\subsection{Umut Sembolü Olarak Mesîh}

Filistinli şair Mahmûd Dervîş, İsrail'in 1996 yılında acımasızca katlettiği 106 köylünün anısına nazmettiği "Rahîlu'l-Cunûd/Ordunun ayrılışı" isimli şiirinde, Mesih'in aslında bu zulme "dur" diyecek umut sembolü bir kişilik olduğunu ifade etmektedir. Şair şöyle demektedir ${ }^{25}$ :

Serseri bir yarın, rüzgârı çiğniyordu

Arkalarında uzun kış geceleri..

Yuşa b. Nûn ${ }^{26}$ 'un ordusu

İkisinin ev taşlarından yapıyorlardı kalelerini

O ikisi, Qana ${ }^{27}$ yolunda bitkin düşüyorlar:

Efendim bir gün buraya uğradı,

Suyu şaraba çevirdi, aşk hakkında çok şeyler söyledi.

Ey oğul dedi: Yarını hatırla!

Ve hatırla! Ordu ayrildıktan sonra,

Nisan otlarının kemirdiği sökülmüş çarmıhı..

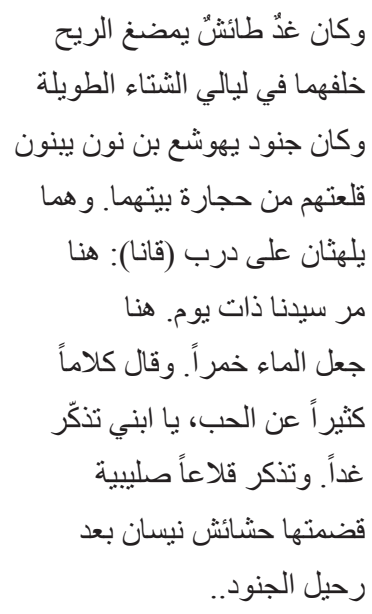

Misırlı Hristiyan şair Emel Dunkul (1940-1983), "Maktelu'l-Kamer/Dolunayın Öldürülmesi” isimli şiirinde dolunayı Mesîh'e benzetmiş ve Mesîh'in nasıl öldürüldüğünü betimlemiştir. Ayrıca her hâlükârda Mesîh'in ölmeyeceğini, çünkü bu tür karakterlerin insanlık için bir umut olduğunu dile getirmektedir. Şiirin tamamı incelendiğinde yaşanılan umutsuzluğun yegâne çaresinin Mesîh olduğu anlaşılmaktadır. Şair şöyle demektedir ${ }^{28}$ :

25 Dervîş, Dîvân, s. 604.

26 Musa Peygamber sonrası İsrailoğulları'nın başına geçen komutan.

271996 yılında İsrail'in saldırısı sonucu 105 sivilin hayatını kaybettiği Beyrut'un köylerinden birisinin adi.

28 E. Dunkul, el-A 'mâlu'l-kâmile, Kahire, Mektebetu Merbûlî, 1987, s. 68. 
Sabah postaları naklettiler bu acı haberi tüm şehirlerde:

Dolunay (Mesîh) öldürüldü!

Çarmıha gerilmiş bir halde, başının bir ağacın üzerinden sarktığını gördüler

Hırsızlar göğsündeki değerli bir elmas kolyeyi de çaldilar

Direkler üzerinde terk ettiler onu

Kör gözümde kara bir mitoloji gibi

Dediler ki; bu çok tuhaf

İnsanlar onu dolunay sandılar, öldürdüler

Sonra da O'na ağladılar

Dolunayın öldürüldüğünü defalarca tekrarladılar

Lakin, babamız ölmez ki..
وتناقلو النبأ الأليم على بريد الثمس في كل مدينة،<smiles>[Mg][AlH2]</smiles>

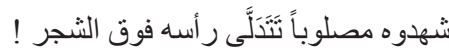
نهب اللصوص قلادة الماس الثمينة من صدره! تركوه في الأعواد ، كالأسطورة السوداء في عيني ضرير قالو ا: غريب ظنه الناس القمر قتلوه ، ثم بكوا عليه ورددوا قُتْل القمر عُيه

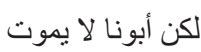

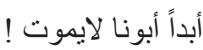

Kesinlikle ölmez babamız.

Sudanlı şair Muhammed el-Feytûrî (1936-2015) “el-Kryâme/Kıyamet” isimli şiirinde Mesih'in insanlık için nasıl bir rol model ve umut kaynağı olduğunu şu sözleriyle belirtmektedir: ${ }^{29}$

Mübarek olsun adımların مبار كة خطو اتكك...

Ey sır dağlarını yerle bir ederek dünyaya geri dönecek kişi

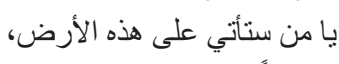
Kutsal 1şı̆̆ın çevrende, göklerin şerefi çevrende Gittiğin gibi geri geleceksin

Ve bizden sileceksin günah ve kiri İşte buradasın... ölümünü tekrar istemektesin Silkindi cesetler yılların ölü toprağından Günleri mübarek olsun...

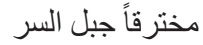

Sarmış çevreni yüce gam Kalbinde haset barındırmaz 
Şerefin miras bırakmaz ölümü

مجدك لا يرث الموت

Yüzüne kibir yakışmaz وجهاك لا يلبس الكبرياء

Filistinli şair Semîh el-Kâsım ise "el-Kasîdetu'l-Mufahfaha/ Hileli Kaside" isimli şiirinde umudunu Mesih'e bağlamış Hristiyan bir kimse olarak şu şekilde münacatta bulunmaktadir ${ }^{30}$ :

Kimsin sen?

$$
\begin{aligned}
& \text { من أنت؟ } \\
& \text { من هذا الذي أنت } \\
& \text { انتظرني يا مسيحي المنتظر } \\
& \text { لم يبق لي أحد سوالك } \\
& \text { وليس لي أحد سواي } \\
& \text { تعال } \\
& \text { إن عناقنا الدموي فاتحة الحقيقة } \\
& \text { نبتدى الخليقة يا أيها البدوي } \\
& \text { لا تنظر ور اءك. }
\end{aligned}
$$

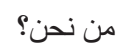

Sendeki bu kim?

Biz kimiz?

Bekle beni ey beklenen Mesihim

Senden başka kimsem kalmadı

Kimsem yok benden başka

Gel ki, boynumuzdan akan kan, hakikatin Fatihası

Gel ki, başlayalım tüm yaratılmışlara ey bedevi

Arkana bakma.

Filistinli şair İzzeddin el-Munâsara (1946-?) “es-Salîb/Çarmıh” adlı şiirinde acılarına çare olmasını umduğu Mesih’i şu şekilde beklemektedir ${ }^{31}$ :

Kara çöllerin sabahında yerlești yağan kar

Şaşırarak titredi yaralı kalbim

Ben çarmıha gerilmiş Mesih'i beklemekteyim

Beklemekteyim çarmıhtaki Mesih'i.

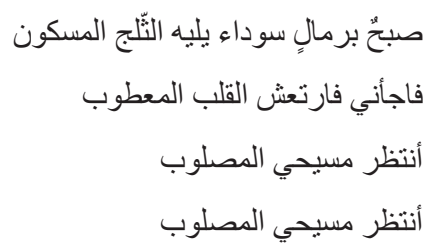

Filistinli şair Ali el-Halîlî (1943-2013) aşağıda bir kısmını verdiğimiz "esSamt/Suskunluk" adlı şiirinde Mesih'in insanlığa nasıl bir umut ve müjde olduğunu şu şekilde dile getirmektedir. Burada Mesih ismi zikredilmemiş ama fakir, müjde, kan ve hurma gibi O'nu çağrıştıran bazı sıfatlar zikredilmiştir. Bilindiği üzere kıyametin alametlerinden birisi de -hem Hristiyan hem de Müslü-

30 el-Kâsım, el-A 'mâlu'ş-şi 'riyyetu'l-kâmile, III/156.

31 İ. el-Munâsara, el-A 'mâlu'ş-şi 'riyye, Beyrut, el-Müessesetü'l- Arabiyye li'd-dirâsât ve'nneşr, 2001, s. 860 . 
manlar nezdinde- Hz. İsa'nın dirilerek geri geleceği inancıdır. Bu bağlamda şair, bir Müslüman olarak düşüncelerini dile getirmiştir. ${ }^{32}$

Taşın sessizliği ürkünç

Konuşmanın sessizliği ürkünç

Vapurların sessizliği ürkünç

$\mathrm{Bu}$ fakirlerin gözündeki hangi sırdır

Dedim ki ey muştunun sırrı

Bu kanlardaki hangi sırdır

Belki de sen hurma idin toprak için

Ve toprak için hurmaydın

$$
\begin{aligned}
& \text { مُوحِشُ صَمتُ الحِجَارة } \\
& \text { مُوحِشُ صنَمتُ الكَلَام } \\
& \text { مُوحِشُ صنمتُ البَوَ اخر } \\
& \text { أيَّ سرٍِ في عيونِ الفقراء } \\
& \text { قُلتُ يَا سِرِّ الِِشَّارة } \\
& \text { أَيُ سِرِّ فِي الذّماء } \\
& \text { رُبَمَا كُنتَتَ تُر ابا للنّخِيل } \\
& \text { وَنَخِيالا لِلتُر اب }
\end{aligned}
$$

\subsection{Kurtarıcı Lider Sembolü Olarak Mesîh}

Mısırlı şair Abdulmu'tî Hicâzî (1935-?), aşağıdaki şiirinde ise kendisini, İsa'yı bekleyen rahibelere benzeterek, O'nun kendisini feda etmesiyle doğanın rengini bulduğunu belirtmiştir. Şaire göre Mesih'in kanı dağ, tepe ve nehirler ise renk suları oluşturmuştur. O'nun yeşil gözleri otlara, saçları ise portakala renk vermiştir. Şaire göre Mesih bir bakıma insanlığ kurtaracak liderdir. Bunu "elMesîh/Mesîh" isimli şiirinde şu şekilde dile getirmektedir ${ }^{33}$ :

Bizler! Karanlığa batmış kadınlarız.

Bizler Mesihimizin,

Yahudilerin kalbinde çarmıha gerilen Mesihimizin dönmesini bekleyen rahibeleriz...

Mesihimizin kanı dağlara, tepelere ve nehirlere saçılmış...

Gözleri ot, saçları portakal rengi gibi parlak

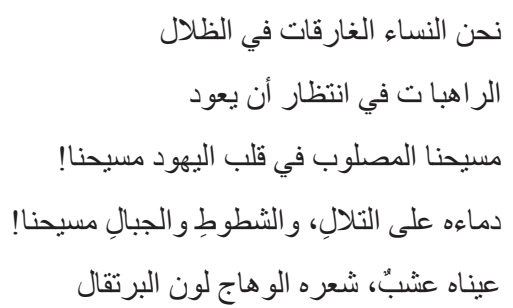
الر اهبا ت في انتظار أن يعود

Iraklı şair Fâdıl ‘Azzâvî (1940-?) “Neşîdu'l-Vesenî/Putperest Marşı” adlı şiirinde kendi zamanındaki Hristiyan inançlilara seslenerek, yeni bir kurtarıcı Mesih'in çıkması durumunda O'nun da asıl Mesih'in yalnızlığa itildiği gibi, asla yalnız bırakılmamasını tembihlemektedir. Şair şöyle demektedir ${ }^{34}$ :

32 A. el-Halîlî, el-A 'mâlu 'ş-şi 'riyyetü'n-nâcize, Ramallah, Vizâratü'-s-sekâfe, Beytü'ş-şi 'r, 2013, $\mathrm{I} / 378$.

33 Hicâzî, el-A 'mâlu'ş-şi 'riyyetu'l-kâmile, s. 313.

34 F. Azzâvî, el-A 'mâlu'ş-şi 'riyyetu'l-kâmile, Beyrut, Menşûrâti'l-cemel, 2007, II/102. 
Ey neslim: Mesih sürgünde nahoş bir şekilde şehit olarak öldü..

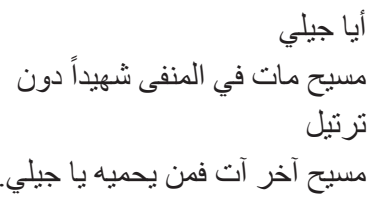

Ey neslim: Ve bas
kim koruyacak.

Lübnanlı şair Halîl Hâvî(1919-1982)“ er-Ra đu’l-Cerîh/Yaralı şimşek” isimli şiirinde İsa Mesih'i kendilerini kurtaracak kahraman bir lidere benzetmektedir. Şair şöyle demektedir ${ }^{35}$ :

Mübarek olsun at sırtında doğum yapan

Ve doğurduğu halde iffetli olan.

Doğurduğu kimse,

Kılıcını ateş kıvılcımlarıyla sulayan bir kahramandır.

Kitabın harfleri parlamaktadır

$\mathrm{Bu}$ alevin kuvvetinden

Ve gizli kâinatın özünden

Alev almaktadır şimşekler.

$$
\begin{aligned}
& \text { وتباركت رحم التي ولدت } \\
& \text { على ظهر الخيول } \\
& \text { ولات وما برحت بتول } \\
& \text { بطلاً يروّي سيفه } \\
& \text { لهب الشهاب } \\
& \text { من منيع الثهب التي التمعت } \\
& \text { حروفاً في الكتاب } \\
& \text { ومضت بروقاً أحرقت } \\
& \text { عن جوهر الكون الحجاب }
\end{aligned}
$$

\subsection{Gurbet ve Vatan Özleminin Sembolü Olarak Mesîh}

Filistinli şair Muhammed el-Kaysî (1944-2003), "Makâtı' min Muduni'l-esfâr/ Şehirlere Yolculuktan Kesintiler” isimli şiirinde Mesih'i yıkan ve üzen şeyin, acı ve işkence olmadığını, bilakis sürgün ve yaşadığı gurbetlik sebebi olduğunu ifade etmiştir. Bir Filistinli için bu ima (telmih) yerinde bir tespittir. Zira Filistinliler de -aynı Muhammed el-Kaysî gibi- yıllardır sürgün hayatı yaşamakta ve vatan hasretiyle tutuşmaktadırlar. Şair şöyle demektedir ${ }^{36}$ :

Mesih'i gördüm rüyamda

Ağliyordu nehir kenarında

Nehir yıkanıyordu dumanlı bulutlar altında

Bana gülümsemedi ama imalı bir şekilde baktı

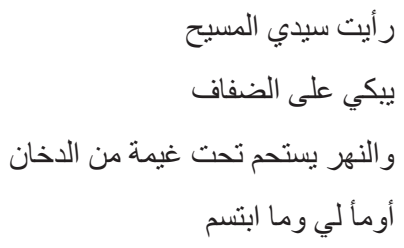

35 H. Hâvî, Dîvân, Beyrut, Dâru'l- 'avde, 2001, s. 467.

36 M. el-Kaysî, el-A 'mâlu'ş-şi 'riyyetu'l-kâmile, Beyrut, el-Müessesetü'l-'Arabiyye li'd-dirâsât. 1999, s. 87. 
Çektiği istıraptan olsa gerek

Suskunluğu itiraf gibiydi

Hüzün atlarına binmiş bir şekilde

Yürümeye başladı

Arap körfezinde gördüm onu

Gurbetlikten şikâyet etmekteydi.

$$
\begin{aligned}
& \text { وكان صمته اعتر اف } \\
& \text { بما يعاني من ألم } \\
& \text { ور اح في تطواف } \\
& \text { رأيته على الخليج } \\
& \text { ممتطيًا خيول الحزن } \\
& \text { يشكو من اغتر اب }
\end{aligned}
$$

\subsection{Izdırap ve Çile Sembolü Olarak Mesîh}

Misırlı şair Salâh Abdussabûr (1931-1981), "Uğniyetu'ş-Şitâ'/Kış Şarkısı" isimli şiirinin bir kısmında kendisini çarmıha gerilip türlü türlü işkencelere maruz kalan Mesih'e benzetmiştir ${ }^{37}$ :

$\mathrm{Bu}$ y1lın kışının bana haber verdiğine göre

ينبئني شتاء هذا العام

Bana şifa olduğunu zannettiklerim bir zehirmiş

Ve bu şiir beni silkelediğinde düşürdü beni

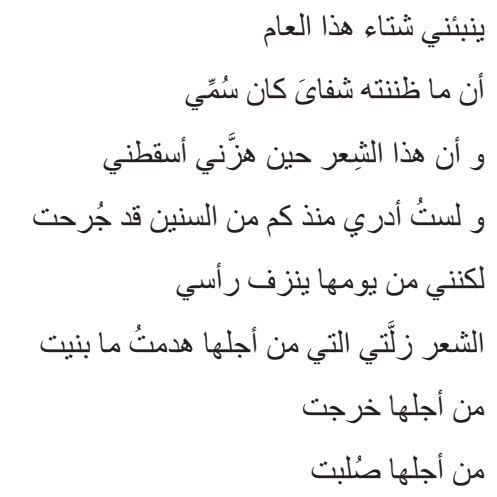

Onun yüzünden çarmıha gerildim

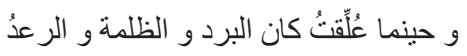

Asıldığımda; soğuk, karanlık ve şimşek korkudan yalvarıyorlard 1

Çağırdığımda kimse koşmadı yardıma

$\mathrm{O}$ an anladım ki, kaybetmiştim kaybettiklerimi ترجُني خوفا

$\mathrm{Bu}$ kışın bana haber verdiğine göre

Kışta yaşamamız için

Yazın sıcaklığını biriktirmemiz
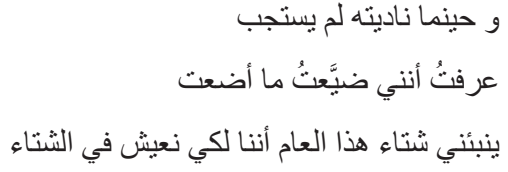

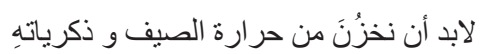

Ve hatıralarını sicak tutmamız gerekir.

Filistinli şair İzzeddîn el-Munâsara, aşağıdaki "Meryemâtu Beyti Lahm/ Beyti Lahm Meryemleri” adlı şiirinde Mesih'in çektiği 1stırabı, kendi halkı olan 37 S. 'Abdussabûr, Dîvân, Beyrut, Dâru'l-'avde, 1973, s. 193. 
Filistinlilerin çektiği istıraba benzetmiştir. Şairin Mecusi ifadesi Yahudileri sembolize edebileceği gibi, Mesih zamanında Filistin'i işgal eden Pers kralı da olabilir. İslam ümmetini yakıp yıkan Moğolları ise, Filistin halkına zulmeden İsrail'e benzetmiştir. Şair şöyle demektedir ${ }^{38}$ :

Ben ve Mesih...

$$
\begin{aligned}
& \text { أنا ..... و المسيح } \\
& \text { ولانا بمنطقة واحدة } \\
& \text { فإذا لم يطر في الصباح جناحي } \\
& \text { وكانت ورائي جيوش المغولن }
\end{aligned}
$$
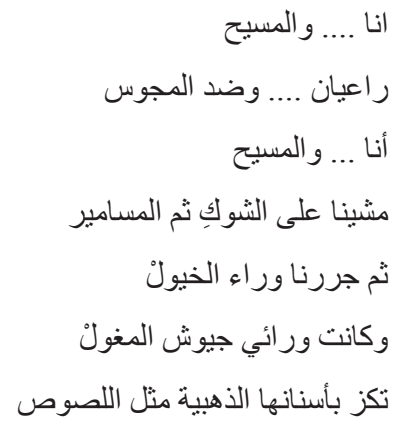

Aynı yerde doğduk

Eğer sabah kanatlarım açılmazsa

Rüzgâra hükmetmen gerekir

Sonra yaralarımı koklarsın

Ben ve Mesih...

Mecusi karşıtı iki çobanız.

Ben ve Mesih...

Yürüdük diken ve çiviler üzerinde

Sonra atlar arkasında sürüklendik

O zaman arkamda Moğol ordusu vardı

Altın dişlerini gıcırdatan hırsız gibi

Aşağı doğru inen tepelerden

Tüm metinleri nehirde boğmak için

İşte o zaman yenildim

Ve kapladı üzerimi karanlık ordusu..

Iraklı şair Muhammed Mehdî el-Cevâhirî "İlâ Sa'd/Sa'd'e" isimli şiirinde Mesih'i katleden Roma'y1, Arap kültüründe uğursuzluk getirdiğine inanılan baykuşa benzetmiş, Mesih'in kanının ta Roma'ya kadar uzadığını belirtmiştir. Şair şöyle demektediri ${ }^{39}$ :

Roma'daki bir baykuş, elinde İsa'nın kanı olduğu halde

Süzülen zeytin ağaçları üzerinde ötmektedir.

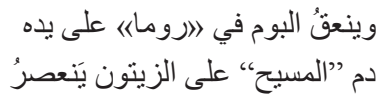




\subsection{Merhamet ve Mağfiret Sembolü Olarak Mesîh}

Filistinli şair İzzeddîn el-Munâsara, "Kuzeyli Meryem" şiirinin bir kısmında Mesih'i merhamet ve mağfiret sembolü olarak ele almıştır. Peygamberlerin genel özelliklerinden birisi olan merhamet, bu şiirde Mesih'i dul, yaralı, garip ve mazlumları merhametiyle kuşatan bir figür olarak betimlemektedir. Şair şöyle demektedir ${ }^{40}$ :

İşte budur... mübarek efendi ذللك هو السيد المبارك

Dulların efendisi سيد الأرامل

Yaralıların efendisi

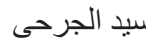

Çöllerin efendisi

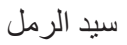

Kurbanların efendisi سبد المذبحة

Tatlı hatıralarını çevirerek arşivden

Sırt üstü uzanmış gülmektedir

"Kuzeyli Meryem Oğullarının kanı"

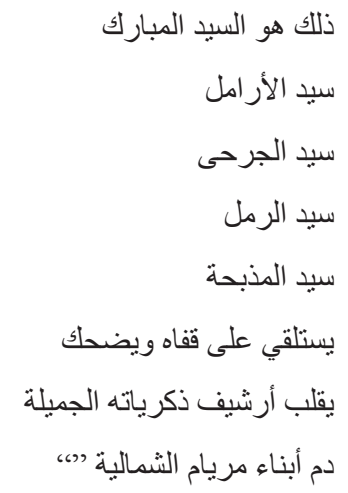

Lübnanlı şair Saê̂d ‘Akl (1911-2014), “el-Mecdeliyye/Mecdeleli” isimli şiirinde Mesih'i temiz ve etrafa kokular saçan bir figüre benzetmiş, inananlarını ise onun gölgesinde merhametiyle gölgelenen diğer çiçeklere benzetmiştir. Şair şöyle demektedir ${ }^{41}$ :

Hazların çiçeği duymuş ki, otların solumasıyla doğar varlık

Tertemizliğin genciyle, güle şarkı söyleyen

الابَّتَّْ زهرةُ اللذائذ أنّ الكونَ بالناثقق

Zor

Güzel kokular

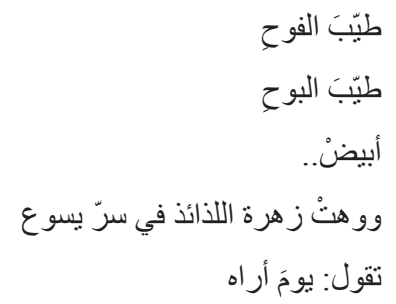

Görünümü hoş ve beyaz...

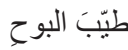

Hazların çiçeği kaybetti gücünü Mesih'in sırrı içinde

“Onu gördüğüm gün...” diyor

40 el-Munâsara, el-A'mâlu'ş-şi 'riyye, s. 481.

41 S. 'Akl, Sa 'îd 'Akl Şi 'ruhû ve'n-nesr, Beyrut, Nobless, 1991, s. 110. 


\section{8. Özdeşleştirme Sembolü Olarak Mesîh}

Iraklı şair Bedr Şâkir es-Seyyâb'ın (1926-1964) öldükten sonra tekrar dirildiğine inanılan bir mitolojik figür olan Temmuz ile ${ }^{42}$ kıyasladığı Mesih konulu bu şiirinin bir kısmında hem özdeşleştirme hem de umut sembolü vardır. Ekmek, hasat, ziraat ve tohum gibi kelimeler her ne kadar Temmuz'u simgelese de Mesih'in akan kanı vasitasiyla hayat bulması veya tekrar dirilmesi Temmuz ile ortak noktasıdır. Şair “el-Mesîhu ba de's-Salîb/Çarmıh Sonrası Mesih" isimli şiirinde şöyle demektedir ${ }^{43}$ :

Ekmeğin ismimle yenmesi ve

Her mevsim hasat edilmek için öldüm

Her çukurda müstakbel ve tohum olmak için

Kaç hayatta dirileceğim:

İnsanların bir nesli oldum

Kanım her bir kalbin içinde

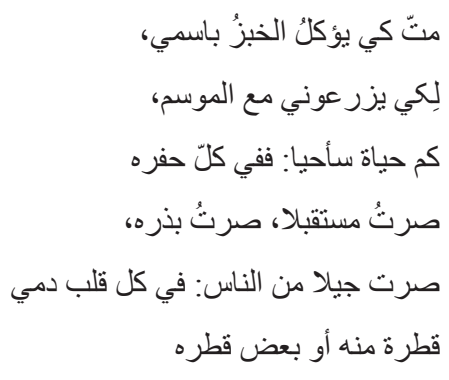

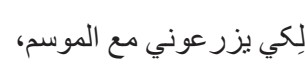

كم حياة سأحيا: ففي كلّ حفره

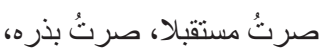

قطرة منه أو بعض قطره

Bazen bir damla bazen daha fazla...

Ürdünlü şair Teysîr es-Sebbûl (1939-1973), “Ahzânu Sahrâ/Çöl Hüzünleri” isimli şiirinde kendisini Mesih'in yerine koyarak adeta kendisini Mesih'le özdeşleştirmiştir. Şair şöyle demektedir ${ }^{44}$ :

42 Bu edebi ve siyasi hareket adını Sümer mitolojisinde geçen, baharı ve yeniden dirilişi simgeleyen İnanna efsanesinden alır. Günümüz Arap dünyasında mevcut siyasal ve sosyal düzene karşı başkaldırının bir ürünü olarak çağdaş Arap şiirinde ortaya çıkmıştır. Temmuz hareketi özellikle 1950'lerde Arapların İsrail'le olan savaşları ardından kaybettikleri topraklar nedeniyle entelektüel çevrelerde büyük tepkilere neden olmuştur. Arap toplumunu dünyadaki gelişmelerden habersiz, tarih girdaplarında uyumaya devam ediyor gören çağdaş Arap şairleri, kendilerine Arap toplumunu bu uykudan uyandırma misyonu yüklemekte, bu misyonu da daha ziyade doğanın canlanıp hayat bulmasını sembolize eden eski doğu medeniyetlerine ait verimlilik mitlerine vurgu yaparak yerine getirmeye çalışmaktadırlar. (Geniş bilgi için bkz: S. Tur, “Çăgdaş Arap Şiirinde Temmuz Şiir Hareketi”, Ekev Akademi Dergisi, yı1 12, sayı 36, s. 352 vd.; R. Kazan, “Arap Edebiyatında Serbest Şiirin İlk Örneklerinden: Bedr Şâkir es-Seyyâb'ın “Unşûdetu'l-Matar /Yağmurun Türküsü” Adlı Şiiir”, SDÜ İlahiyat Fakültesi Dergisi, y1l 2015/1, say1 34, s. 28 vd.

43 B. Ş. es-Seyyâb, Unşûdetu'l-matar, Kahire, Müessesetu Hindâvî, 2015, s. 112.

44 T. es-Sebbûl, Ahzân Sahrâviyye, Amman, Dâru'l-Yâzûrî el- 'ilmiyye, 2001, s. 12. 
Ağzımda gözyaşının acılığını hissediyorum.

Bakışlarımda yoğun bir karanlık yayılmakta

Mesih neden beni feda etti ey kardeşler

Sizler göz bebeğimin arkasındasınız

Sizleri çarmıha gerip, yaraladım

Ve sizden önce kalbimi yaraladım

Ve İsis ${ }^{45}$ dualarımla beni aldattığında

Gülüşleriniz yağmurlar yağdırdı ruhuma

Ve bir gün, göğe yükselerek esmeye başladı

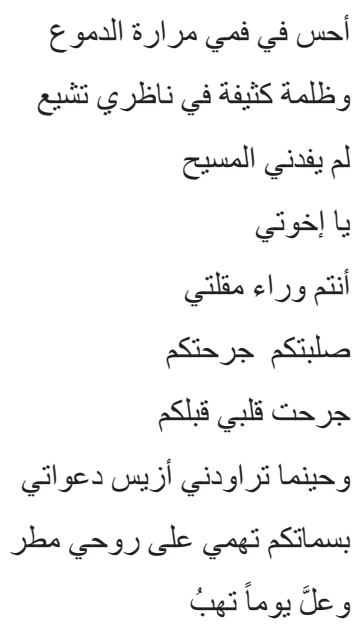

Suriyeli şair Adonis (1931-?) “el- Asru'z-Zehebî/Altın Çă̆” isimli şiirinde kendisini Mesîh ile özdeşleştirmiştir. Aralarındaki ortak nokta suçluluktur. Şaire göre Mesîh dönemin muhalif bir lideridir ve kendisi de bu dönem muhaliflerindendir: ${ }^{46}$

Sürükle onu ey polis

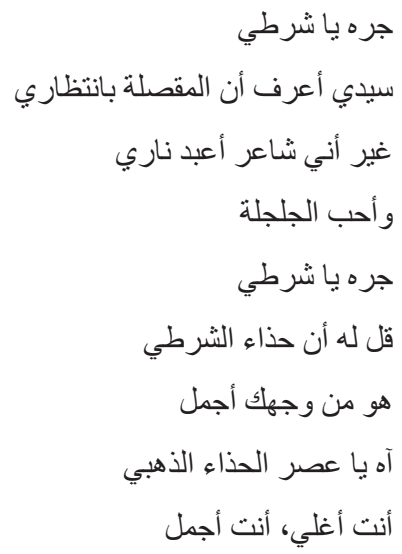

Efendim... Bilirim ki giyotin beni beklemekte

Bunun dışında ben sadece kendi ateşime tapan bir şairim

Ve çan sesini de severim

Sürükle onu ey polis

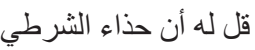

Ve deki ona; polis ayakkabısı

Yüzünden daha güzeldir

Ah! Ey altın ayakkabı asrı

Sen ne pahalı ve ne güzelsin...

Filistinli şair Mahmûd Dervîş "Cidâriyyât/Duvarlar" isimli şiirinde kendisini Mesih'e benzetmiş fakat yükseklik ve kıyamet gibi bazı korkularından ötürü Mesih'in yaptıklarını yapamayacağını da ifade etmiştir. Şair şöyle demektedir ${ }^{47}$ :

45 Misır mitolojisinde kutsal kraliçe ve cennetlerin annesi olan tanrıça.

46 Adonis, Âsâru'l-kâmile, Beyrut, Dâru'l-avde, 1971, I/446.

47 M. Derviş, Cidâriyyât, Beyrut, Riyâd er-Reyyis li'l-kutub, 2001, s. 46. 
İsa'nın göl üzerinde yürüdüğü gibi

Ben de yürüdüm rüyamda

Fakat ben çarmıhtan indim.

Çünkü ben yüksekten korkarım

Ve kiyameti de müjdeleyemem...

$$
\begin{aligned}
& \text { مثلما سار المسيحُ على البحيرة } \\
& \text { سرتُ في رؤيايَ. } \\
& \text { لكني نزلتُ عن الصليب } \\
& \text { لأنني أخشى العلوّ، } \\
& \text { ولا أبشَرُ بالقيامة. }
\end{aligned}
$$

Libyalı şair Alî el-Fezzânî (1937-2000), "es-Salîb/Çarmıh” adlı şiirinde kendisini Mesih yerine koymuş, Mesih'in çektiği işkence ve azabı duygu dünyasında yaşayarak, kendisini Mesih'le şu şekilde özdeşleştirmiştir. Şair şöyle demektedir: ${ }^{48}$

Beni

Dalları üzerinde yüksek sesle ağıtların yakıldığı,

Aşağılık bir ağaçta çarmıha gerdiler.

Ben, gökteki ilahtan vahiy alan peygamber olduğumu söylemedim

Ama ben, sırtımda çarmıhımla geri döndüm bir gün.

Yolumu bulmaya çalışıı patikalarımda

O’nu buldum ve beraber yürüdük

Çıplak ayakla, günahkâr olarak...

Çocuklar alkışlayarak,

Bak işte Mesih yeryüzüne tekrar döndü dediler.

$$
\text { صلبوني فوق أعو اد حقيره }
$$$$
\text { من غصون قد تغنى فوقها شادٍ ونائح }
$$$$
\text { لم أقلها إنني كنت نبيا }
$$$$
\text { أنلقى الوحي من إله في الأعالي }
$$

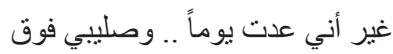

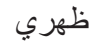$$
\text { وتلمست طريقي عبر دربي }
$$$$
\text { فوجدته ومشيته }
$$$$
\text { حافياً ندمي خطاب }
$$$$
\text { صفق الأطفال ... ها قد عاد للأرض }
$$$$
\text { المسيح }
$$

Mısırlı şair Necîb Surûr, "el-Vilâde/Doğum” isimli duygularını paylaştığı şiirinin bu kısmında, hayat zorluğu ve yaşanmazlığ kendisini işkence göreceği çarmıhı sırtında taşımaya zorlanan Mesih'e benzetmiş, bu şekilde kendisini Mesih ile özdeşleşmiştir. Şair şöyle demektedir ${ }^{49}$ :

Bu gün sırtımda bir çarmıhla çıktım evimden

Cebim harap

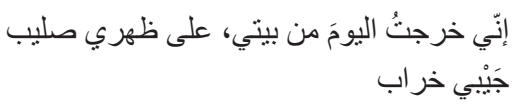

48 'Alî el-Fezzânî, el-A'mâlu'ş-şi 'riyyetu'l-kâmile, Trablus, el-Menşeetü'l- âmme li'n-neşr, 1983, s. 25.

49 Surûr, et-Trajedya el-ínsâniyye, s. 39. 
Kalbim harap

Bir böcek gibi hissettim kendimi,

Evliya kubbelerinden daha büyük bir ayakkabıyla ezilen...

Göremediğim bir şey var orada, korkunç bir şey...

Ey kardeşler... İşte akşam oldu

Ve döndüm kasvetli evime

Sırtımdaki haç ile yürümekteyim

Cebim harap

Kalbim harap

Etimdeki elmas harap...

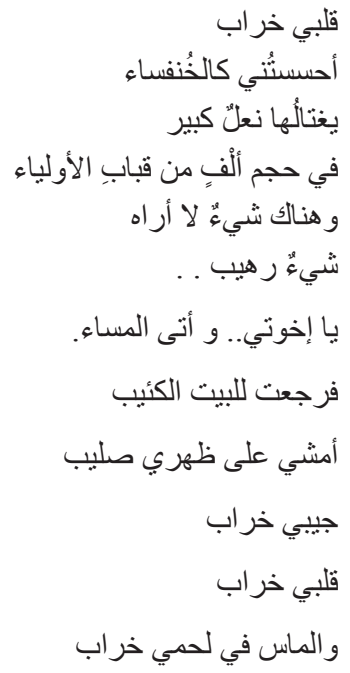

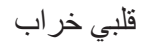

في حجم الفٍ من فباب

يا إخوتي.. و أنى المساء.

فرجعت للبيت الكئيب

أمشي على ظهري صليب

جيبي خر اب

قاب تلبي خر اب

و الماس في لحمي خر اب

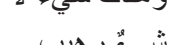

\subsection{Yalnızlık Sembolü Olarak Mesîh}

Iraklı şair Muhammed Mehdî el-Cevâhirî rejim muhalefeti sebebiyle yaşamak zorunda bırakıldığı ülkede, yaşamakta olduğu yalnızlık duygusunu Mesih'in yalnızlığına eş tutmaktadır. Şair şöyle demektedir ${ }^{50}$ :

$$
\text { و وما برح السؤال بلا مجيبٍٍ }
$$

"Sorular cevapsiz kalmaya devam etti

Ve kafalar kaldırılmadı topuklardan

Altmış bin kişi kaldırmadı mı hala başlarını

Ve kaçmakta yakındaki ta uzaklara

Ve silmeye çalışmakta çocuğu

Tıpkı, Mesih'in haçı sildiği gibi

Şarap sunmaktayım geniş bir ovada

Soylu, edip veya akıllı bir yardımcım olmadan..." 
Muhammed Mehdî el-Cevâhirî "Londra'dan Kırıntılar" isimli şiirinde ise yine, Mesih'in Yahudiler arasındaki yalnızlığı ile kendisinin Londra' da yaşadığı yalnızlığını aynı görmektedir. Şair şöyle demektedir ${ }^{51}$ :

Sıkıldım Londra'daki ikametimden

Genelevler arasındaki bir bakire gibi

Yahudiler arasındaki Mesih'in ikameti

İşkence ikameti gibi yorucudur

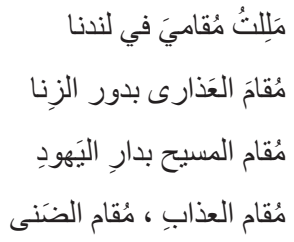

\subsection{Pasif Kişilik Sembolü Olarak Mesîh}

Libyalı şair Abdülhamîd Batâu (1941-?), şiirinin alıntısını yaptığımız bu kısmında sanki Mesih'i eleştirir gibi bir hal içerisindedir. Zira Mesih savaş ve mücadele karşıtı pasif bir duruş sergilemiştir. Hatta İncil'deki ifadeye göres "eğer biri sana tokat atarsa, diğer yanağını da dön" gibi sözleri mevcuttur. Sanki şair kendi toplumunu Mesih nezdinde pasif bir duruşla suçlamaktadır. Zira Arap toplumunun Filistin hususunda kaygısız ve tepkisiz kalmas1, Dünya ülkeleri tarafından kale alınmaması Mesih'in bu öğretisinin bir tezahürü gibidir. Bu durumda şair Mesih ve ideolojisine karşı çıkarak, eğer mücadele ruhu olmazsa, zillet içerisinde yaşamak zorunda kalındığını ifade etmektedir. Şair, şöyle demektedir ${ }^{53}$ :

Söyleme sakın tarihin dolu olduğunu, لا تقل لي : إن التواريخ زاخرة بالذين إذا صُفعو ا

Tokat yiyince bunu affederek karşılayanlarla... واجهو ا صافعيهم بعفو صريح

Söyleme sakın bana Mesih olduğunu...

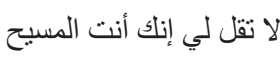

Yaşamakta olduğumuz zaman çok çirkin فالزّمان الذي نحن فيه

Zulme direniş göstermeden boyun eğen زمان قبيح

Zelil ve hakir bir şekilde yaşayacaktır.

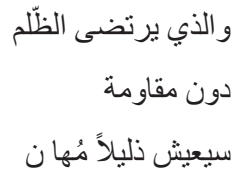

51 el-Cevâhirî, Dîvân, III/229.

52 Matta, 5/39.

53 A. Batâu, Dîvânu terâkimi'l-umûri's-sa 'be, Trablus, 1976, s. 62. 


\subsection{Masumiyet Sembolü Olarak Mesîh}

Mısırlı şair Emel Dunkul “Maktelu'l-kamer/Dolunayın Öldürülmesi” isimli şiirinde Mesîh'in kendileri tarafından ihanete uğradığını bildirmiştir. Burada Mesîh masumiyet sembolüdür. Şair şöyle demektedir: ${ }^{54}$

Ey köyümüzün evlatları... Babanız öldü

O’nu şehrin çocukları öldürüp

Yusuf'un kardeşleri gibi gözyaşı döktüler

Sonra dağıldılar

Ve O'nu öfke ve kan dolu asfalt cadde üzerinde terk ettiler

Ey kardeşim: İş̧te bu ölen babanızdır.

$$
\begin{aligned}
& \text { يا أبناء قريتنا أبوكم مات } \\
& \text { قد قتلته أبناء المدينة } \\
& \text { ذرفو ا عليه دموع إخوة يوسف الفئه } \\
& \text { وتفرقوا } \\
& \text { تركوه فوق شو ارع الإسفلت و الدم } \\
& \text { و الضغينة } \\
& \text { يا أختي : هذا أبوكم مات! }
\end{aligned}
$$

\section{Sonuç}

Modernizm hayatın her alanını olduğu gibi, edebiyata bakışı da değiştirmiştir. Edebiyat temaları romantik veya nostaljik olmaktan çıkarak, hak, hukuk, açlık, sefalet, zulüm, savaş, salgın gibi hayatla daha iç içe konuları ele almaya başlamıştır. İnsanlığın hayatını kolaylaştırmakla beraber, daha çok yıkımlara sebebiyet veren sanayi devrimi sonrasında; insan özgürlüğü, barış, evrensel ahlak, sorgulama, mutluluk ve insan aklına güven gibi ilkeler etrafinda şekillenmiş, bir takım ilkelere bağlı bu akımların en önemlilerinden birisi de şüphesiz sembolizmdir.

Yirminci yüzyılın ilk çeyreğinde Arap şiiri, gerek şekil, gerekse konu açısından klasik dönemden çok farklı bir çizgiye yönelmiştir. Batı'da öğrenim görmüş, Batı edebiyatlarını okumuş ve bunların etkisinde kalmış Arap şair ve yazarların sayısı her geçen gün artmıştır. Bu süreçte Arap edip ve aydınlar tarafından kurulan İhyâ, Dîvân, Mehcer, Apollo, Mecelletü'ş-Şi`r ve Temmuzî gibi edebi ekol ve cemiyetler sayesinde, Arap toplumu Batı ile entegre olmada çok hızlı yol almıştır. Temmuzî akım denilince akla sembolizm gelmektedir. Çünkü sembolizmin Arap edebiyatına yansıması bu edebi akımla zirveye çıkmıştır. İsrail devletinin kurularak, Filistin'i işgali, Arap-İsrail savaşı sonrası Arapların bir avuç İsrailli’ye yenilmesi gibi sebepler, sanat amaçlı ortaya çıkan sembolizmin Arap âleminde siyasallaşmasına sebebiyet vermiştir. Yukarıda sayılan trajik olaylar çağdaş Arap şairini, zaten felsefesi kapalılık olan sembolizmi daha da kapalı bir hale getir- 
miştir. Diktatörlükle yönetilen Arap ülkelerindeki şairler liderleri eleştirdikleri için pek çoğu bedel ödemek zorunda kalmıştır. Bu bedelin başında sürgün ve ölüm korkusuyla yaşam vardır. Nitekim bu durum bir zamanlar Türkiye'de dahi yaşanmıştır.

Sonuç olarak İsa Mesih, hem Müslüman hem de Hristiyan şairler arasında Arap sembolizmimin en gözde figürlerinden birisidir. İsa Mesih bu bağlamda modern Arap şairlerine ilham veren rehber gibidir. $\mathrm{Bu}$ çalışmada bunun sebeplerini açıklamaya çalıştık. Ayrıca bu konunun metinlerarasılık bağlamında da incelenmesi gerekirdi. Fakat bu defa çalışma çok hacimli olacağından bundan vazgeçerek, sonraki çalışmalara bıraktık. 


\section{Kaynakça}

Abbâs, İhsân, İtticâhâtu şi'ri'l-'Arabiyyi'l-mu'âsır, Kuveyt, Âlemu>lma'rife, 1998.

Adonis, Âsâru'l-kâmile, Beyrut, Dâru'l- avde, 1971.

Akl, Sa îd, Sa 'îd 'Akl Şi'ruhû ve'n-nesr, Beyrut, Nobless, 1991.

el-'Azzâvî, Fâdıl, el-A 'mâlu'ş-şi 'riyyetu'l-kâmile, Beyrut, Menşûrâti'l-cemel, 2007.

el-Batâu, Abdülhamîd, Trablus, Dîvânu terâkimi 'l-umûri's-sa 'be, 1976.

el-Cevâhirî, M. Mehdî, Dîvân, Beyrut, Beysân li'n-neşr ve’t-tevzî, 2005.

Cevizci, Ahmet, Felsefe Sözlüğ̈̈, İstanbul, Paradigma Yayıncılık, 2010.

Ceylan, Zafer, Modern Arap Şiirinde Mito-Poetik İsyan, Konya, Çizgi Kitabevi, 2019.

el-Ceyyûsî, Selmâ Hadrâ, el-İtticâhât ve'l-harekât fi'ş-şi 'ri'l- 'Arabiyyi 'l-hadîs, terc. Abdulvâhid Lu'lu'e, 2. bs., Beyrut, Merkezu dirâsâti'l-vahdeti'l- Arabiyye, 2007.

Çetin, Nihat, Eski Arap Şiiri, İstanbul, Kapı Yayınları, 2011.

Çetişli, İsmail, Batı Edebiyatında Edebi Akımlar, Ankara, Akçağ Yayınları, 2017.

Demirayak, Kenan, Abbasi Dönemi Arap Edebiyatı, Erzurum, Şafak Kitabevi, 1998.

Dervîş, Mahmûd, Dîvân, Beyrut, Dâru'l-'avde, 2004. , Cidâriyyât, Beyrut, Riyâd er-Reyyis li'l-kutub, 2001.

Dunkul, Emel, el-A 'mâlu'l-kâmile, Kahire, Mektebetu Merbûlî, 1987.

Fâhûrî, Mahmûd, Mûsîkâ eş-Şi'ri'l- 'Arabî, Haleb, Menşûrât kulliyyeti'l-âdâb bi Câmi'ati Haleb, 1996.

el-Feytûrî, Muhammed, Şarku'ş-şems garbu'l-kamer, Lübnan, Dâru'ş-şurûk, 1992.

el-Fezzânî, Ali, el-A 'mâlu'ş-şi riyyetu'l-kâmile, Trablus, el-Menşeetü'l- âmme li’n-neşr, 1983.

el-Halîlî, Ali, el-A 'mâlu'ş-şi 'riyyetü'n-nâcize, Ramallah, Vizâratü'-s-sekâfe, Beytü'ş-şi'r, 2013.

Hâvî, Halîl, Dîvân, Beyrut, Dâru'l-'avde, 2001. 
Heddâre, Muhammed Mustafa, Dirâsâtun fi'l-edebi'l-'Arabiyyi'l-hadîs, Beyrut, Dâru'l- 'ulûmi'l-'Arabiyye, 1990.

Hicâzî, Abdülmu'tî, el-A'mâlu'ş-şi'riyyetu'l-kâmile, Kahire, el-Hey'etü'l-'amme li kitâb, 2014.

'Iyâd, Şükrî Muhammed, el-Mezâhibu'l-edebiyye ve'n-nakdiyye 'inde'l-'Arab ve'l-Ğarbiyyîn, Kuveyt, 'Âlemu'l-ma rife, 1993.

Kabeş, Ahmed, Târîhu'ş-şi 'ri'l-'Arabiyyi'l-hadîs, Beyrut, Dâru'l-cîl, 1971.

el-Kâsım, Semîh, el-A 'mâlu'ş-şi 'riyyetu'l-kâmile, Beyrut, Dâru Sa'âd es-Sabâh, 1993.

el-Kaysî, Muhammed, el-A 'mâlu'ş-şi 'riyyetu'l-kâmile, Beyrut, el-Müessesetü'l-'Arabiyye li'd-dirâsât, 1999.

Kazan, Ramazan, “Arap Edebiyatında Serbest Şiirin İlk Örneklerinden: Bedr Şâkir es-Seyyâb'ın “Unşûdetu'l-Matar /Yağmurun Türküsü” Adlı Şiir”, SDÜ İlahiyat Fakültesi Dergisi, 2015/34.

Kefeli, Emel, Batı Edebiyatında Akımlar, 2. bs., İstanbul, Dergâh Yayınları, 2014.

Küçük, Mehmet, Modernite Versus Postmodernite, İstanbul, Say Yayınları, 2011.

Şeyho, Luis, Târihu'l-âdâbi'l-'Arabiyye, Beyrut, Dâru'l-meşrik, 1991.

Neşâvî, Nesîb, Medhal ilâ dirâseti'l-medârisi'l-edebiyye fì şi 'ri'l-'Arabiyyi 'l-mu 'âsır, Cezair, Dîvânu'l-matbû' âti'l-câmi iyye, 1984.

Safa, Peyami, Edebi Akımlar ve Fikir Cereyanları, İstanbul, Boğaziçi Yayınlar1, 2007. 2001.

es-Sebbûl, Teysîr, Ahzân Sahrâviyye. Amman, Dâru'l-Yâzûrî el-'ilmiyye,

es-Seyyâb, Bedr Şâkir, Unşûdetu'l-matar, Kahire, Müessesetu Hindâvî, 2015.

Surûr, Necîb, et-Trajedya el-insâniyye, Kahire, Vizâratu's-sekâfe, 1967.

eş-Şâbbî, Ebu'l-Kâsım, el-Hayâlu 'ş-şi 'rî inde'l- 'Arab, Kahire, Kelimât 'Arabiyye li't-terceme ve'n-neşr, 2013.

et-Tunusî, Muhammed Hıdır Hüseyin, el-Hayâlu fi'ş-şi 'ri'l- 'Arabî, Dimaşk, el-Mektebetu'l-'Arabiyye, trs. 
Tur, Salih, "Çăgdaş Arap Şiirinde Temmuz Şiir Hareketi”, Ekev Akademi Dergisi, 12/36.

Usta, İbrahim, İslam Öncesi Arap Mitolojisi, Ankara, Ankara Okulu Yayınları, 2019.

Yalar, Mehmet, Modern Arap Şiiri, Bursa, Arasta Yayınları, 2003. 